\title{
PELATIHAN DAN PENGUASAAN DIGITAL MARKETING DALAM MENINGKATKAN PENDAPATAN PARA REMAJA DI LINGKUNGAN BENDA TIMUR IV
}

\author{
${ }^{1}$ Jasmani, ${ }^{2}$ Lucia Maduningtias, ${ }^{3}$ Irmal \\ Dosen Fakultas Ekonomi Universitas Pamulang \\ Email : 1]djasmany@yahoo.com
}

\begin{abstract}
ABSTRAK
Tujuan kegiatan ini adalah mengadakan pelatihan dan penguasaan digital marketing dalam meningkatkan pendapatan para remaja di lingkungan Benda Timur IV. Metode yang digunakan adalah ceramah, tanya jawab, diskusi dan praktik. Hasil kegiatan ini menjadikan para remaja di lingkungan Benda Timur IV Tangerang Selatan dapat menguasai digital marketing.

\section{Kata Kunci : Pemasaran, Digital Marketing.}

\section{PENDAHULUAN}

Hasil survei "Coming of Age on Screens" yang dilakukan oleh Crowd DNA pada 11.000 remaja di kalangan usia 13-24 di 13 negara, termasuk di Indonesia, baru saja dirilis awal Juli ini. Dari survei yang digelar pada April-Mei 2014 itubertepatan dengan musim liburan sekolah-terungkap aneka temuan menarik yang dapat dijadikan insight bagi marketers yang memang mengincar konsumen remaja. Tak mengherankan, jika $72 \%$ remaja setuju bahwa memiliki teknologi atau gadget terbaru itu adalah penting.

Sebanyak 69\% remaja di Indonesia mengatakan bahwa mereka merasa ketinggalan informasi jika mereka tidak dapat mengakses social media. Sejalan dengan tingginya pengguna Facebook di Tanah Air, rupanya 79\% remaja di Indonesia juga menyebutkan bahwa Facebook dapat mendokumentasikan kegiatan mereka. Tak tanggung-tanggung, sebanyak 81\% remaja di Indonesia mengaku bahwa Facebook membuat mereka merasa lebih dekat dengan orang yang mereka kenal. Temuan lain yang dapat dipelajari dari hasil survei ini adalah tingkat ketertarikan remaja Indonesia terhadap mobile. Mereka $(69 \%)$ rupanya lebih memilih tidak memiliki televisi dibandingkan tidak memiliki handphone. Sementara itu, sebanyak 8 dari 10 remaja atau sekitar 79\% mengatakan mereka akan berbagi konten brand yang menarik yang mereka temukan jika konten tersebut menarik secara visual. Buntutnya, $86 \%$ remaja menginginkan konten yang lebih menyenangkan dari brand.
\end{abstract}




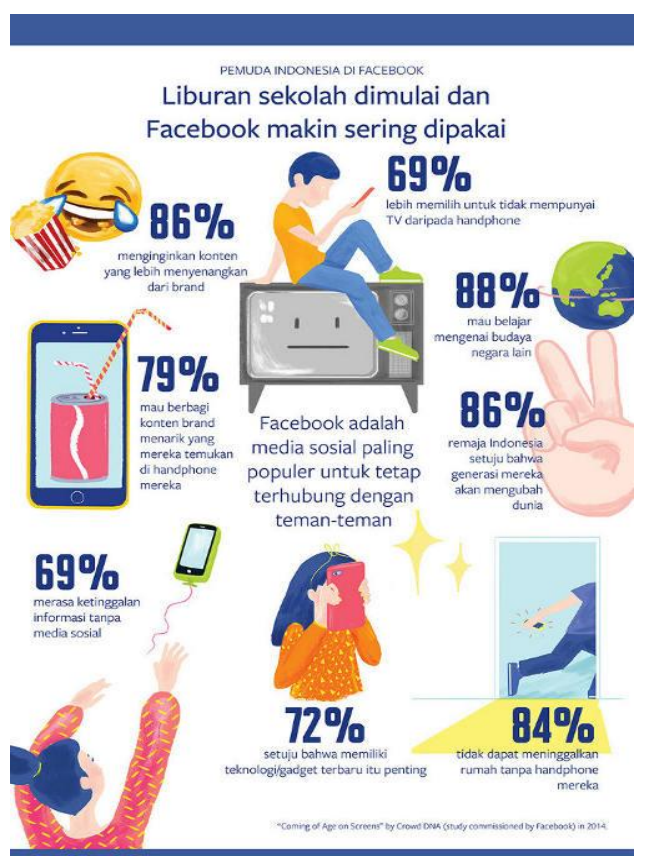

$\begin{array}{rcr}\text { Sementara itu, remaja } & \text { Indonesia } \\ \text { sekarang ini rupanya senang }\end{array}$ mengekspresikan diri mereka melalui foto, video, emoticon, dan emoji-yang mampu memberikan wacana baru untuk kosa kata secara visual, bahkan sering menggantikan kebutuhkan akan teks. Oleh karena itu, marketers dituntut untuk erkomunikasilah dengan segmen remaja melalui bahasa yang mereka bicarakan dan pahami.

Namun, kepercayaan dan relevansi adalah kuncinya. Itu sebabnya, 53\% dari mereka setuju bahwa mereka senang berinteraksi dengan brand melalui media sosial. Akan tetapi, 56\% mengatakan mereka hanya mau memperhatikan iklan dari merek yang mereka percaya.

Yang lebih menarik, remaja Indonesia ternyata memiliki tingkat optmistik tertinggi dibandingkan negara lain. Dari 55\% remaja di global setuju bahwa generasi mereka akan mampu mengubah dunia, Indonesia menempati posisi tertinggi, yakni mencapai $86 \%$. Selanjutnya, diikuti oleh India (81\%) dan Amerika (60\%).

\section{METODE PELAKSANAAN KEGIATAN}

Metode yang digunakan adalah ceramah, tanya jawab, diskusi dan praktik.

Tahap Pertama: Tahap Persiapan.

Tahap persiapan meliputi persiapan materi pelatihan, persiapan tempat pelatihan,persiapan peserta pelatihan, tenaga fasilitator dan instruktur yang terdiri dari dosen dan mahasiswa, penentuan waktu pelaksanaan pelatihan serta persiapan sarana dan prasarana. Tahap kedua : Tahap Pengembangan

Tahap pengembangan meliputi pemaparan digital Marketing.

Tahap Ketiga : Tahap Evaluasi

Tahap evaluasi meliputi kegiatan diskusi dan penilaian.

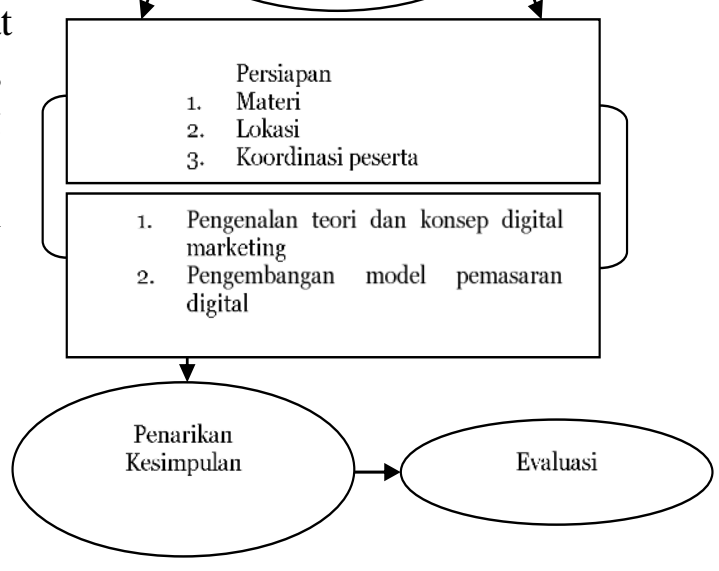
Tahap Keempat: Tahap Penutup

Tahap penutup meliputi acara ramah tamah dan foto bersama. 


\section{HASIL DAN PEMBAHASAN}

Marketing adalah serangkaian proses yang dilakukan untuk memasarkan produk atau mengenalkan produk kepada masyarakat dengan berbagai cara, agar produk tersebut menjadi banyak diminati oleh masyarakat luas. Sehingga dalam hal ini pengertian marketing tidak hanya sebatas saat terjadi pemasaran, namun juga mengenai strategi yang digunakan, serta cara memberikan kepuasan kepada konsumen.

Marketing adalah bagian penting dari suatu perusahaan. Melalui kegiatan tersebut, barang dari produsen bisa sampai kepada konsumen. Oleh sebab itu, marketing sering disebut sebagai penghubung produsen dan konsumen. Strategi marketing harus jelas. Hal ini perlu dilakukan agar barang dari produsen dapat sampai kepada konsumen dalam waktu yang

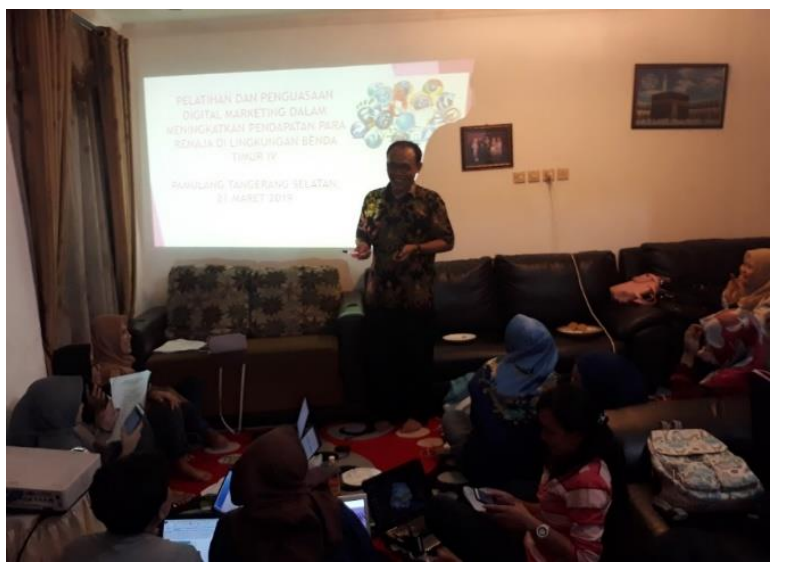
tepat. Strategi ini perlu dilakukan untuk menghindari terjadi kekecewaan konsumen.

Tipe pemasaran digital mencakup banyak teknik dan praktik yang terkandung dalam kategori pemasaran internet. Dengan adanya ketergantungan pemasaran tanpa internet membuat bidang pemasaran digital menggabungkan elemen utama lainnya seperti ponsel, SMS (pesan teks dikirim melalui ponsel), menampilkan iklan spanduk, dan digital luar. Pemasaran digital turut menggabungkan faktor psikologis, humanis, antropologi, dan teknologi yang akan menjadi media baru dengan kapasitas besar, interaktif, dan multimedia. Hasil dari era baru berupa interaksi antara produsen, perantara pasar, dan konsumen. Pemasaran melalui digital sedang diperluas untuk mendukung pelayanan perusahaan dan keterlibatan dari konsumen.

Pemasaran melalui e-mail/surel disebut e-mail komersial. Penggunaan email dalam bisnis dapat membantu pengiriman informasi (promosi) mengenai produk atau jasa pada receiver (penerima pesan). CAN-SPAM Act adalah sebuah hukum yang menetapkan aturan-aturan untuk e-mail komersial.

Sender Score adalah sebuah layanan gratis, di mana algoritma Sender Score memberi rating terhadap reputasi setiap alamat IP server mail dengan skala 0-100. Dengan mengumpulkan data dari lebih 60 juta mailbox di ISP-ISP besar mereka merekam apakah orang sering melakukanunsubscribe atau melaporkan spam dari pengirim email tertentu, dan kemudian memberikan skor pengirim berdasarkan pemantauan tersebut. Sender Score akan terus berubah tergantung pada kebiasaan mengirim email dan respon dari para penerima.

Sender Score adalah sebuah angka penting untuk tetap berada di posisi teratas, karena mail server akan sering memeriksa Sender Score sebelum 
memutuskan apa yang akan mereka lakukan terhadap suatu email. Semakin rendah Sender Score, maka semakin sulit untuk suatu email masuk ke inbox seseorang. Ada banyak hal yang bisa berdampak pada keterkiriman email, tetapi laporannya menyatakan bahwa $83 \%$ email tidak terkirim ke inbox, disebabkan karena reputasi pengirim yang buruk.

Bahkan jika sebuah jaringan email atau ISP tidak menelusuri suatu Sender Score untuk menentukan apakah mereka akan mengirim email tersebut atau tidak, namun faktor-faktor yang digunakan dalam menentukan Sender Score mirip dengan yang digunakan oleh jaringan-jaringan email dan ISP untuk menentukan reputasi pengirim. Oleh karena itu, skor ini merupakan alat reputasi pengirim email yang sangat baik dan gratis untuk memastikan menyadari dan memiliki kesempatan untuk memperbaiki setiap masalah keterkiriman.

\section{KESIMPULAN DAN SARAN}

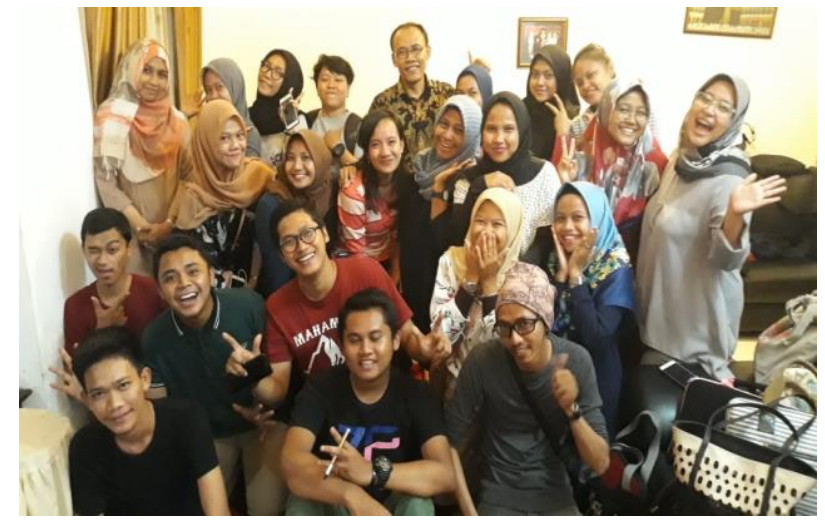

Dengan kegiatan ini menjadikan para remaja di lingkungan Benda Timur IV Tangerang Selatan dapat menguasai digital marketing, peserta memberikan tanggapan yang baik, hal ini dapat dilihat dari dukungan mereka dalam setiap kegiatan yang di adakan, sehingga dapat membantu menerima segala bentuk informasi ilmu pengetahuan dan teknologi yang datang dari luar untuk meningkatkan pendapatan bagi kesejahteraan dimasa yang akan datang.

\section{DAFTAR PUSTAKA}

Kotler, Philip, Alih Bahasa A.B. Susanto.2002. Manajemen Pemasaran di Indonesia, Analisis, Perencanaan, Implementasi dan Pengendalian. Jakarta: Penerbit Salemba Empat.

Pranoto, P., Jasmani, J., \& Marayasa, I. N. (2019). Pelatihan Digital Marketing Untuk Peningkatan Perekonomian Anggota Karang Taruna Al Barkah Di Kampung Cicayur-Tangerang. Jurnal Pengabdian Dharma Laksana, 1(2), 250-258.

Jasmani, J. (2019). Pengaruh Product Development Dan Promotion Mix Terhadap Peningkatan Penjualan Yang Berdampak Pada Keunggulan Bersaing. Jurnal Ekonomi Efektif, 1(2).

Jasmani, J. (2019). Pengaruh Promosi Dan Pengembangan Produk Terhadap Peningkatan Hasil Penjualan. Jurnal Semarak, 1(3). 